\title{
Sediment transport processes across the Tibetan Plateau inferred from robust grain-size end members in lake sediments
}

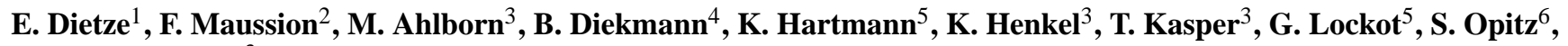 \\ and T. Haberzettl ${ }^{3}$ \\ ${ }^{1}$ Section 5.2 Climate Dynamics and Landscape Evolution, GFZ German Research Centre for Geosciences, Potsdam, Germany \\ ${ }^{2}$ Chair of Climatology, Technische Universität Berlin, Berlin, Germany \\ ${ }^{3}$ Physical Geography, Institute of Geography, Friedrich-Schiller-Universität Jena, Jena, Germany \\ ${ }^{4}$ Alfred Wegener Institute for Polar and Marine Research, Research Unit Potsdam, Potsdam, Germany \\ ${ }^{5}$ Institute of Geographical Sciences, EDCA, Freie Universität Berlin, Berlin, Germany \\ ${ }^{6}$ Institute for Earth and Environmental Sciences, Universität Potsdam, Potsdam, Germany
}

Correspondence to: E. Dietze (edietze@gfz-potsdam.de)

Received: 12 July 2013 - Published in Clim. Past Discuss.: 21 August 2013

Revised: 29 November 2013 - Accepted: 4 December 2013 - Published: 16 January 2014

\begin{abstract}
Grain-size distributions offer powerful proxies of past environmental conditions that are related to sediment sorting processes. However, they are often of multimodal character because sediments can get mixed during deposition. To facilitate the use of grain size as palaeoenvironmental proxy, this study aims to distinguish the main detrital processes that contribute to lacustrine sedimentation across the Tibetan Plateau using grain-size end-member modelling analysis. Between three and five robust grain-size end-member subpopulations were distinguished at different sites from similarly-likely end-member model runs. Their main modes were grouped and linked to common sediment transport and depositional processes that can be associated with contemporary Tibetan climate (precipitation patterns and lake ice phenology, gridded wind and shear stress data from the High Asia Reanalysis) and local catchment configurations. The coarse sands and clays with grain-size modes $>250 \mu \mathrm{m}$ and $<2 \mu \mathrm{m}$ were probably transported by fluvial processes. Aeolian sands $(\sim 200 \mu \mathrm{m})$ and coarse local dust $(\sim 60 \mu \mathrm{m})$, transported by saltation and in near-surface suspension clouds, are probably related to occasional westerly storms in winter and spring. Coarse regional dust with modes $\sim 25 \mu \mathrm{m}$ may derive from near-by sources that keep in longer term suspension. The continuous background dust is differentiated into two robust end members (modes: 5-10 and 2$5 \mu \mathrm{m}$ ) that may represent different sources, wind directions and/or sediment trapping dynamics from long-range, upper-
\end{abstract}

level westerly and episodic northerly wind transport. According to this study grain-size end members of only fluvial origin contribute small amounts to mean Tibetan lake sedimentation (19 $\pm 5 \%$ ), whereas local to regional aeolian transport and background dust deposition dominate the clastic sedimentation in Tibetan lakes (contributions: $42 \pm 14 \%$ and $51 \pm 11 \%$ ). However, fluvial and alluvial reworking of aeolian material from nearby slopes during summer seems to limit end-member interpretation and should be crosschecked with other proxy information. If not considered as a stand-alone proxy, a high transferability to other regions and sediment archives allows helpful reconstructions of past sedimentation history.

\section{Introduction}

The Tibetan Plateau is the world's largest mountain plateau with an average elevation of $4300 \mathrm{~m}$ above sea level (a.s.l.). It plays an important role for global climate and continent-wide water supply (Immerzeel et al., 2010). Various circulation systems, including the Asian monsoons and the westerlies, interact along a climate gradient from south-east to northwest (e.g. Kutzbach et al., 1993; Böhner, 2006). Summers are dominated by moist summer monsoonal air masses, local convection and cyclonic circulation from plateau heating. Winters are dry and cold, but have much stronger, continuous 
winds due to the influence of the westerlies (Maussion et al., 2013). Due to the high altitude of the plateau, the wind patterns are strongly related to the mid-troposphere circulation, but are also influenced by orography and seasonal plateau heating (Maussion et al., 2013). The spatio-temporal variability of these circulation patterns and their respective influence on regional climate are still under debate (Xu et al., 2007; Liu et al., 2009; Immerzeel et al., 2010).

The Tibetan Plateau hosts around 6880 lakes larger than $0.1 \mathrm{~km}^{2}$ and 7 lakes larger than $500 \mathrm{~km}^{2}$ (Kropáček et al., 2013). Lakes are fed mainly by summer precipitation, glacial melt and to a minor extent by melting permafrost (Liu et al., 2009). These lakes can contain highly resolved, continuous sediment records that can be used to reconstruct past circulation patterns using a variety of biological, geochemicalmineralogical, and sedimentological proxy information (e.g. Mischke et al., 2009; Kasper et al., 2012; Opitz et al., 2012). However, to decipher the complex interactions of regional climate and other drivers of environmental change it is necessary to disentangle the associated processes that translate environmental change into properties, which can be stored in archives over longer times.

Detrital particles reach lakes, which are often the final depocentres, from multiple sediment sources and via different transport processes (fluvial, aeolian, glacial) along local or regional sediment cascades (Stauch and Lehmkuhl, 2003). The size distribution of detrital particles is one of the standard parameters used for sedimentary facies description and discrimination of sediment sources (e.g. Folk and Ward, 1957; Torres et al., 2005; Flemming, 2007). Natural grainsize distributions are composed of dynamic subpopulations that were sorted by different sediment production, transport and accumulation processes (Weltje and Prins, 2007). These processes sort sediments in a characteristic way depending on properties of sediment sources, availability, local surface roughness and transport energies (wind strength, flow and shear velocities; Tsoar and Pye, 1987).

If sediments were mixed, for example in the water column, by biotic activity and/or geochemical alterations (Cohen, 2003) or sampling procedure, mean grain-size information were often interpreted in terms of sediment core position relative to the shore and related to lake level changes (Kasper et al., 2012; Opitz et al., 2012; Dietze et al., 2013; Doberschütz et al., 2013). However, the often used deterministic approaches of descriptive moments of single samples (Folk and Ward, 1957; Blott and Pye, 2001) are limited and rather inappropriate for multimodal grain-size distributions derived from high-dimensional state-of-the-art laser-diffraction analysis. The statistical decomposition of grain-size data into their original subpopulations offers more proper and detailed information on sedimentation dynamics (Dietze et al., 2012).

Decomposition currently includes the fitting of theoretical functions to individual samples (Sun et al., 2002; Bartholdy et al., 2007), where often some prior knowledge of the natural subpopulation is needed (Flemming, 2007) and a geo- scientific understanding and interpretation of the fitting parameters is rather complicated. Another approach uses all available samples from a certain archive and unmixes the detrital subpopulations with end-member modelling analysis (EMMA; Weltje, 1997; Dietze et al., 2012). EMMA contributes to a better "operationalism" in particle size analysis (Hartmann, 2007) and is based on principles of numerical inversion to reduce redundancy. It considers compositional data constraints and provides sedimentologically interpretable grain-size end members (Weltje, 1997; Dietze et al., 2012). EMMA has been successfully applied to the multimodal grain-size distributions of marine, lacustrine, and aeolian sediments mainly in the Atlantic ocean and the Asian continent (e.g. Stuut et al., 2002; Vriend and Prins, 2005; Weltje and Prins, 2007; IJmker et al., 2012; Dietze et al., 2012, 2013), where different end members were interpreted as proxies of sediment transport processes.

This contribution aims to disentangle sediment transport and deposition signals from lake sediments exhibiting complex grain-size distributions to facilitate a more detailed interpretation of grain-size proxies in future palaeoenvironmental reconstructions. Using end-member modelling analysis it studies grain-size distributions and the robust endmember subpopulations of lacustrine sediment records from six sites across the Tibetan Plateau. The records were chosen to cover different lake-catchment systems, site conditions, and timescales integrating new gridded contemporary windshear data. This will allow the general characterisation of the most important and typical sediment transport processes that lead to deposition of clastic sediment in Tibetan lakes. However, it is not the scope of this study to disentangle local effects of sedimentation or different local contributions of sediment transport processes at a certain time. This will follow in future detailed spatial and temporal comparisons.

\section{Study sites}

Sediments from five lakes of different surface areas $(0.0145$ to $\sim 2000 \mathrm{~km}^{2}$ ) and one peat bog were studied, which are located between 4090 and 4720 ma.s.l. at the north-eastern Tibetan Plateau (i.e. lake Donggi Cona, Qinghai province) and across the southern Tibetan Plateau (all other sites, Xizhang province, China; Fig. 1; Table 1). The lakes were chosen to have different maximum water depths $(9-220 \mathrm{~m})$ and varying catchment sizes $\left(4.6\right.$ to $\sim 10000 \mathrm{~km}^{2}$; Table 1$)$. Sediment cores were retrieved at water depths between 8.4 and $220 \mathrm{~m}$ at different distances to the shore and at one peat bog site that was a lake system in the past (Table 2). Few perennial streams and several episodically filled minor channels feed the lakes with water derived mainly from summer monsoonal precipitation and to a minor part from snow melt. Lakes Nam Co, Taro Co and Tangra Yumco further receive glacial meltwaters (Wrozyna et al., 2010; Long et al., 2012; Fig. 1). Only lake Donggi Cona has an outflow since ca. 4 cal ka BP (Opitz 
Table 1. Information on lake systems used in this study.

\begin{tabular}{|c|c|c|c|c|c|c|c|}
\hline Lake system* & $\begin{array}{l}\text { Latitude } \\
{\left[{ }^{\circ} \mathrm{N}\right]}\end{array}$ & $\begin{array}{l}\text { Longitude } \\
{\left[{ }^{\circ} \mathrm{E}\right]}\end{array}$ & $\begin{array}{l}\text { Present } \\
\text { altitude } \\
\text { [m a.s.1.] }\end{array}$ & $\begin{array}{l}\text { Lake } \\
\text { size } \\
{\left[\mathrm{km}^{2}\right]}\end{array}$ & $\begin{array}{c}\text { Catchment } \\
\text { size } \\
{\left[\mathrm{km}^{2}\right]}\end{array}$ & Salinity & $\begin{array}{l}\text { References on } \\
\text { lake systems } \\
\text { and catchments }\end{array}$ \\
\hline Targo Xian & 30.77 & 86.67 & 4700 & 0 & 11.8 & fresh & Miehe et al. (2013) \\
\hline TT Lake & 31.10 & 86.57 & 4750 & 0.015 & 4.6 & fresh & unpublished data \\
\hline Donggi Cona & 35.26 & 98.60 & 4090 & 235 & 3028 & fresh & $\begin{array}{l}\text { Dietze et al. (2010), Opitz et al. (2012), } \\
\text { Stauch et al. (2012) }\end{array}$ \\
\hline Taro Co & 31.17 & 84.20 & 4570 & 474 & 7423 & fresh & unpublished data \\
\hline Tangra Yumco & 31.25 & 86.72 & 4550 & 824 & 9893 & brackish & Wang et al. (2010) \\
\hline Nam Co & 30.74 & 90.79 & 4720 & 1966 & 8952 & brackish & $\begin{array}{l}\text { Wang et al. (2009), Wrozyna et al. (2010), } \\
\text { Kasper et al. (2012, 2013) }\end{array}$ \\
\hline
\end{tabular}

\footnotetext{
* See Fig. 1 for location.
}
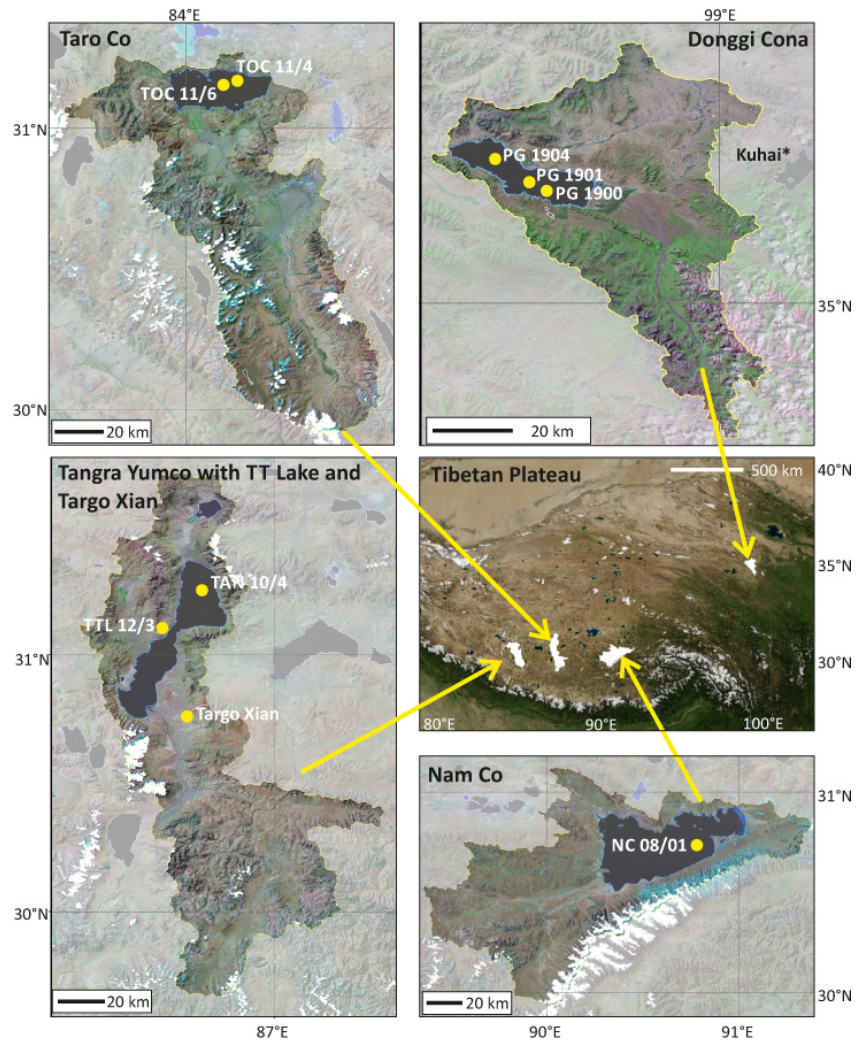

Fig. 1. Studied lakes and their catchments on the Tibetan Plateau, China (for references see Table 1). Map sources: Blue Marble Next Generation, NASA Earth Observatory, 2013 (overview); Landsat ETM+ and SRTM-3, NASA Earth Observatory and USGS, 2001 (catchments); white glaciers from GLIMS Glacier Database, NSIDC, 2013. (*) Lake Kuhai near lake Donggi Cona was studied by Mischke et al. (2009). See kmz-file in Appendix for further information.

et al., 2012) and Targo Xian was part of Lake Tangra Yumco in the past (Miehe et al., 2013). All other lakes are closed lake systems today.
Vegetation in the catchments is composed of semi-arid short-grass steppe, mat-forming Kobresia, Artemisia dwarfshrubs and intercalated Cyperaceae-swamps (Kürschner et al., 2005; Miehe et al., 2013) with lower vegetation cover and open soil patches towards the westernmost lake Taro Co (Fig. 1). All lakes are ice covered in wintertime during most of the years, although a complete ice cover may only be obtained at the large lakes during cold, but calm winters (Kropáček et al., 2013). Geological, geomorphological and pedological inventories vary strongly within and among the catchments but were studied preliminarily only for lakes Nam Co (Keil et al., 2010) and Donggi Cona (Dietze et al., 2010; IJmker et al., 2012; Stauch et al., 2012).

\section{Methods}

\subsection{Laboratory analysis}

Total (in-)organic matter contents varied below (7 and $45 \%$ ) 6 and $12 \%$ in all the cores (Opitz et al., 2012; Ahlborn, unpublished data) with peat phases at Targo Xian containing up to $17 \%$ (Miehe et al., 2013). To study the detrital fraction of the lake sediment composition all sediments were pretreated with hydrogen peroxide $\left(\mathrm{H}_{2} \mathrm{O}_{2}, 15 \%, 30 \%\right)$ until no further reaction occurred indicating that all organic matter was removed. To remove carbonates sediments analysed at the Friedrich Schiller University of Jena (Nam Co, Tangra Yumco, TT Lake, Targo Xian, Taro Co) were treated with hydrochloric acid $(\mathrm{HCl}, 15 \%)$, whereas the Donggi Cona sediments analysed at Alfred Wegener Institute Potsdam were pretreated with acetic acid $\left(\mathrm{CH}_{3} \mathrm{COOH}, 10 \%\right)$. Each treatment leads to comparable results (P. Schulte, RWTH Aachen, unpublished data). After adding sodium pyrophosphate $\left(\mathrm{Na}_{2} \mathrm{HPO}_{4} \cdot 10 \mathrm{H}_{2} \mathrm{O}\right)$ samples were put in an overhead shaker for $12 \mathrm{~h}$. After $10 \mathrm{~s}$ of ultra-sonic bath samples were measured in several cycles until a reproducible signal was obtained using the Fraunhofer optical model in Beckman Coulter laser diffraction particle size analysers LS 13320 
Table 2. Information on lake sediment records used in this study.

\begin{tabular}{llllllccc}
\hline Lake system* & $\begin{array}{l}\text { Sediment } \\
\text { core } \\
\text { name }\end{array}$ & $\begin{array}{l}\text { Latitude } \\
{\left[{ }^{\circ} \mathrm{N}\right]}\end{array}$ & $\begin{array}{l}\text { Longitude } \\
{\left[{ }^{\circ} \mathrm{E}\right]}\end{array}$ & $\begin{array}{l}\text { Core } \\
\text { length } \\
{[\mathrm{m}]}\end{array}$ & $\begin{array}{l}\text { Time } \\
\text { period } \\
{[\mathrm{ka}]}\end{array}$ & $\begin{array}{l}\text { Water } \\
\text { depth } \\
{[\mathrm{m}]}\end{array}$ & $\begin{array}{l}\text { Distance } \\
\text { to shore } \\
{[\mathrm{km}]}\end{array}$ & Reference \\
\hline Targo Xian & Targo Xian core & 30.7667 & 86.6667 & 3.6 & $\sim 11$ & 0 & 0 & Miehe et al. $(2013)$ \\
TT Lake & TTL 12/3 & 31.1029 & 86.5734 & 0.89 & $\sim 1.5$ & 8.4 & 0.02 & unpublished data \\
Donggi Cona & PG 1900 & 35.2601 & 98.6027 & 4.23 & $\sim 14$ & 37.6 & 2.34 & Opitz et al. (2012) \\
Donggi Cona & PG 1904 & 35.3336 & 98.4824 & 4.46 & $\sim 12$ & 39.5 & 3.45 & Opitz et al. (2012) \\
Donggi Cona & PG 1901 & 35.2786 & 98.5621 & 5.72 & $\sim 20$ & 40.0 & 2.67 & Opitz et al. (2012) \\
Taro Co & TOC11/04 & 31.1689 & 84.2019 & 1.22 & $\sim 7.5$ & 68.0 & 2.866 & unpublished data \\
Taro Co & TOC11/06 & 31.1561 & 84.1493 & 0.9 & $\sim 3$ & 123.0 & 5.2 & unpublished data \\
Tangra Yumco & TAN 10/04 & 31.2526 & 86.7228 & 1.62 & $\sim 3$ & 220.0 & 4.683 & unpublished data \\
Nam Co & NC 08/01 & 30.7374 & 90.7903 & 1.15 & $\sim 4$ & 93.0 & 7.525 & Kasper et al. (2012) \\
\hline
\end{tabular}

* See Fig. 1 for location.

(Jena) and LS 200 (Potsdam). No systematic measurement bias is to be expected in grain-size data sets measured in Jena and in Potsdam (J. Stucki, Beckman Coulter GmbH Germany, personal communication, 2013).

\subsection{End-member modelling analysis (EMMA)}

Grain-size data was analysed separately for each lake system. All particle size data from Donggi Cona cores PG-1900, PG-1901, and PG-1904 retrieved in similar water depths were compiled in a matrix for a joint evaluation of the same lake system. For Taro Co (TOC) EMMA was performed separately for each core and combined thereafter to see if water depth and distance to the shore affected the results. Event layers (differentiated by fining-upwards facies and distinct colour changes) are difficult to assess with EMMA, as they represent a single process affecting all grain-size fractions in contrast to the size-sorting processes that are of interest here. It was attempted to exclude these layers as best as possible (i.e. $\sim 16$ and $40 \%$ of the samples were removed from Tangra Yumco and TT Lake). Generally, grain-size classes containing zero values in all samples were ignored to avoid numerical instabilities (Table 3). All samples were recalculated to the constant sum of $100 \%$ (Dietze et al., 2012).

EMMA extracts end members from the eigenspace of a data set. An end member consists of loadings, which are the representation of the end member in the variable space (here: grain-size class) and scores, the composition in the sample space. The loadings were scaled to be genetically meaningful (scale and unit according to original data; Weltje, 1997) using a weight transformation after Klovan and Imbrie (1971). The scores will be discussed elsewhere in the frame of multiproxy palaeoenvironmental reconstructions. Grain-size end members were calculated after Dietze et al. (2012) using extensions implemented in the R package EMMAgeo (Dietze and Dietze, 2013).
Dietze et al. (2012) showed that from different similarlylikely end-member models some end members had modes at almost identical grain-size fractions. The less an endmember loading varies and the more often it occurs, when using different similarly-likely model runs, the more robust it is. For the similarly-likely models the number of end members $\boldsymbol{q}$ can be varied between $q_{\min }$ and $q_{\max }$ (Dietze et al., 2012). Similarly, the quantile range ( $\boldsymbol{l}$ ) ("percentile" in Dietze et al., 2012) included in the weight transformation may range between zero (Miesch, 1976) and a maximum quantile $\left(l_{\max }\right)$ defined as the highest possible quantile allowing numerically stable weight transformations. The weight transformation reduces scale and outlier effects by standardizing to a certain range of the data. The ranges of $\boldsymbol{q}$ and $\boldsymbol{l}$ can result in potentially infinite numbers of endmember models. For computation efficiency we used a sequence of $50 \boldsymbol{l}$ values. From combinations of $\boldsymbol{l}$ and the likely range of $\boldsymbol{q}$ only robust and interpretable end-member models were selected. Robust end members (rEM) are defined using the following criteria: (a) unmixing of subpopulation had to be effective and was measured by calculating the overlap of the modes in the end-member loadings. Only models with non-overlapping, interpretable end-member loadings were included and (b) similar end-member loadings should occur in most of the similarly-likely model runs (high frequency of modes in the same or directly adjacent grain-size classes) as determined from histogram-plots (Figs. 2a).

The mean total variance of each end member was calculated to assess the relative importance of each end member in each data set. Furthermore the best-possible parametrisation of an end-member model is given with an optimal weight quantile $\left(l_{\mathrm{opt}}\right)$, which resulted in the highest explained variance compared to all other $\boldsymbol{l}$ and an optimal number of $\operatorname{EM}\left(q_{\mathrm{opt}}\right)$ at the inflection point within the $Q-R_{\text {mean }}^{2}$ plot of the $l_{\text {opt }}$ model in consensus with previous works (Weltje and Prins, 2007). 
Table 3. Input and boundary parameters for similarly-likely end-member model runs for robust end-member (rEM) calculation and optimal EMMA ( $l_{\max }$ and $l_{\text {opt }}$ refer to maximum and optimal weight quantiles; $q_{\text {opt }}$ indicates the optimal number of end members; see text and Dietze et al., 2012).

\begin{tabular}{lllllllll}
\hline Site/core & $\begin{array}{l}\text { No. of } \\
\text { samples }\end{array}$ & $\begin{array}{l}\text { No. of } \\
\text { non-zero } \\
\text { grain size } \\
\text { classes }\end{array}$ & & $l_{\text {max }}$ & $l_{\text {opt }}$ & $\begin{array}{l}\text { No. of } \\
\text { included } \\
\text { models* }\end{array}$ & $\begin{array}{l}\text { No. } \\
\text { of } \\
\text { rEM }\end{array}$ & $\begin{array}{l}\text { Total } \\
R_{\text {mean }}^{2} *\end{array}$ \\
\hline Targo Xian & 86 & 92 & 0.052 & 0.031 & 129 & 5 & 0.850 & 5 \\
TT Lake & 53 & 89 & 0.028 & 0.005 & 241 & 5 & 0.889 & 4 \\
Donggi Cona & 128 & 85 & 0.012 & 0.008 & 225 & 4 & 0.841 & 4 \\
TOC11/4 & 122 & 71 & 0.061 & 0.010 & 91 & 5 & 0.891 & 5 \\
TOC11/6 & 90 & 72 & 0.028 & 0.014 & 119 & 3 & 0.837 & 3 \\
TOC all & 212 & 72 & 0.012 & 0.010 & 249 & 5 & 0.876 & 5 \\
Tangra Yumco & 136 & 74 & 0.011 & 0.004 & 164 & 4 & 0.908 & 4 \\
Nam Co & 92 & 66 & 0.016 & 0.016 & 128 & 3 & 0.860 & 2 \\
\hline
\end{tabular}

* Mean robust EM model.

\subsection{Wind data}

To interpret the observed end members in the context of the recent climate, data from the High Asia Reanalysis was used (HAR, Maussion et al., 2011, 2013; http://www.klima. tu-berlin.de/HAR, available for the time period 2001-2011). To consider aeolian sediment transport pathways and energies, the hourly surface wind fields at $10 \mathrm{~m}$ height (wind speed and direction) and the wind shear velocity field were extracted from the $10 \mathrm{~km}$ resolution products. They were averaged for for the seasons December-January-February (DJF), March-April-May (MAM), June-July-August (JJA), and September-October-November (SON).

\section{Results}

\subsection{EMMA statistics}

All sediment records showed multimodal grain-size distributions with different modes or shoulders in the individual samples (Fig. 2b). Calculating similarly-likely EM models resulted in a distinct pattern of EM loadings (i.e. grain-size subpopulations) for each data set (Fig. 2b). In general, histograms indicated between three and five highly frequent primary modes of the loadings at certain grain-size classes (Fig. 2a). Compared to the original multimodal distributions, these rEM subpopulations were clearly unmixed. The mean and standard deviations of these robust end-member loadings, numbered according to the position of their primary mode from coarse to fine grain-size fractions, are shown in Fig. 2b.

As an example, Fig. 3 shows illustrative plots for the Nam Co data set using a sequence of $10 l$ indicating how $q_{\max }$, $l_{\text {max }}, l_{\text {opt }}$, and $q_{\text {opt }}$ were determined (automatically provided in R package EMMAgeo, Dietze and Dietze, 2013; for $q_{\min }$ see Dietze et al., 2012) and which models resulted in over- lapping end-member loadings. Table 3 summarizes these parameters for all data sets. These boundary parameters are not associated, which means the total number of samples, nonzero grain-size classes, optimal number of EM ( $\left.q_{\text {opt }}\right)$ or number of included similarly-likely EM models does not affect the number of robust EM or the mean total variance they explain.

Some sites (e.g. Tangra Yumco) showed rather clear rEM loading patterns with very small deviations from the mean indicating a high robustness of the resulting end members. Some sites had rEM that were very robust (e.g. Targo Xian rEM 3-5, Fig. 2). Others were less robust as these may explain only a small part of variance (rEM1 of TOC11/6 and both TOC cores, Fig. 2).

Important features are the smaller secondary modes observed in all loadings independent of laboratory pretreatment. In all cases except for rEM2 of the Nam Co data set they represent numerical artefacts as they appear below the primary modes of other end members. We assume that the secondary modes arise from the orthogonality and linearity constraint in EMMA, because due to measurement procedures and the sedimentary processes itself the eigenspace is likely non-linear. However, Dietze et al. (2012) found that oblique rotations resulted in less interpretable end members, which is why orthogonal constraints were kept. Here, the secondary mode artefacts were masked out to allow a better comparison and discussion of the major modes (Fig. 4).

\subsection{Robust end-member loadings}

EMMA of the TOC11/4-core and the NC08-1 core produced three rEM explaining 83.7 and $86.0 \%$ of the mean total variance (Table 2). Four rEM occurred in the TT Lake, Donggi Cona and Tangra Yumco data sets explaining 81.4, 84.1 , and $90.8 \%$ of the mean total variance. The most frequent end member in the TT Lake data set in the coarse 
(a)
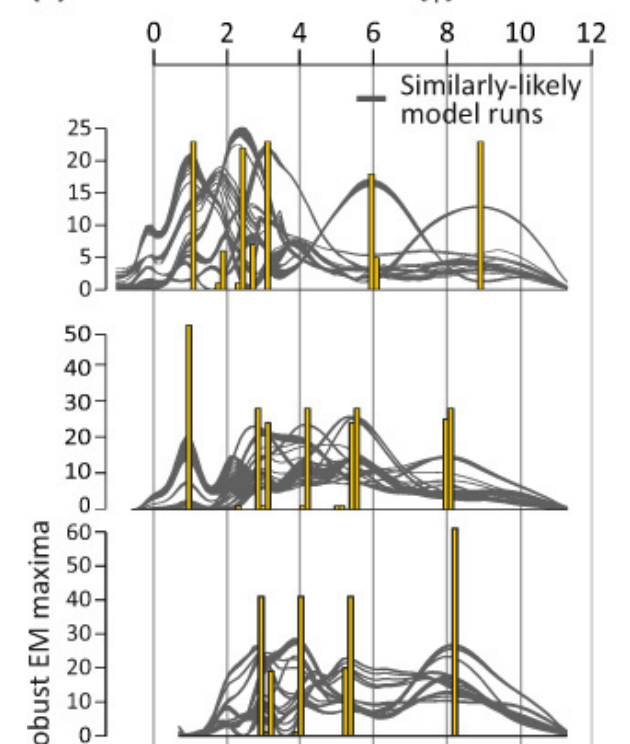

20

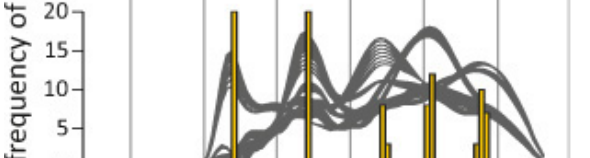

t 0

듄 40

$\frac{\pi}{d} 30$

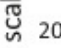

$\pm 10-$

¿ 0

点 15

15
5
0
40

$40-$

30

20
10

0

$\left.\begin{array}{r}25 \\ 20- \\ 15- \\ 10- \\ 5- \\ 0\end{array}\right]$

$$
1000
$$

Grain size $[\phi]$ (b)
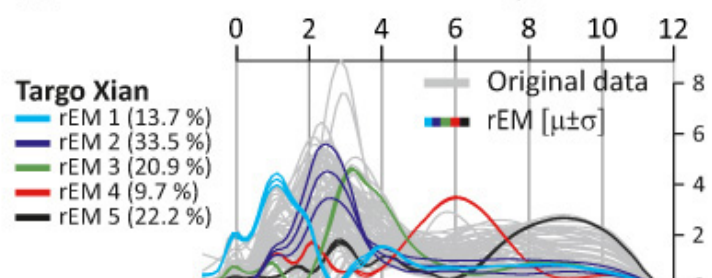

TT Lake

- rEM 1 (19.7\%)

- $\mathrm{rEM} 2(17.1 \%)$

- rEM $3(21.1 \%)$

一 rEM 4 (42.1\%)

Donggi Cona

- rEM 1 (8.8\%)

- rEM $2(33.2 \%)$

- $\operatorname{rEM} 3(13.7 \%)$

- rEM 4 (44.2\%)

TOC11/4

- rEM 1 (12.5\%)

- rEM $2(21.8 \%)$

$-\operatorname{rEM} 3(8.7 \%)$

- rEM $4(34.9 \%)$

- rEM $5(22.1 \%)$

TOC11/6

- rEM 1 (5.9\%)

- rEM $2(47.8 \%)$

- rEM $3(46.3 \%)$

TOC all

- rEM $1(1.2 \%)$

- rEM $2(22.3 \%)$

- rEM $3(32.9 \%)$

- rEM $4(23.0 \%)$

- $\operatorname{rEM} 5(20.5 \%)$

Tangra Yumco

- $\operatorname{rEM} 1$ (3.4\%)

- $\mathrm{rEM} 2(25.4 \%)$

- $\operatorname{rEM} 3(38.2 \%)$

- $\operatorname{rEM} 4(34.0 \%)$

Nam Co

- rEM 1 (38.7\%)

- rEM $2(9.0 \%)$

$-\operatorname{rEM} 3(52.3 \%)$

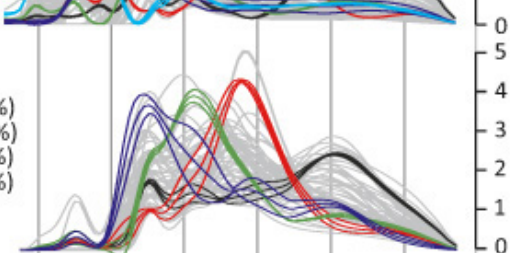

\section{\%)}
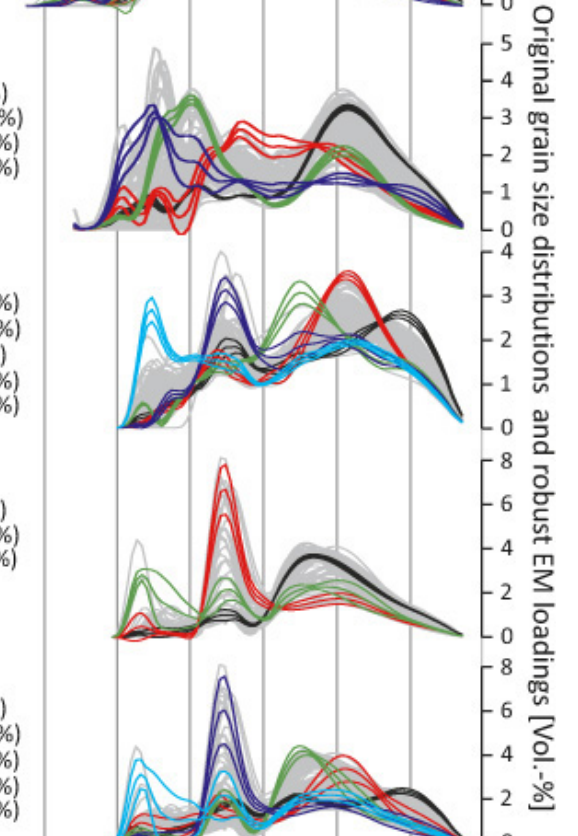

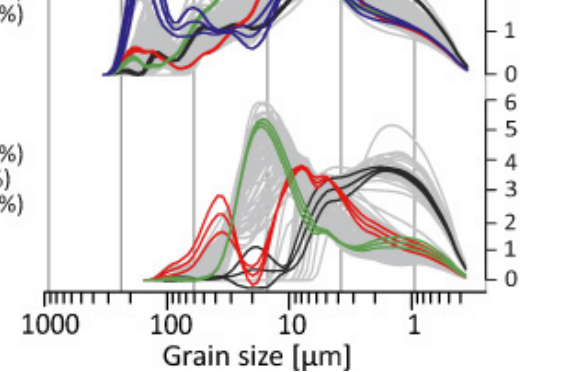

Fig. 2. Results of robust end-member modelling for the studied lake sites (sorted according to lake size). (a) End-member (EM) loadings for more than 90 similarly-likely EM model runs (grey graphs) including the frequency of their primary modes (yellow bars) indicating the position of the robust end members. (b) Robust end-member (rEM) loadings (coloured, $\mu \pm \sigma$, in brackets: explained variances of each EM) compared to the original grain-size distributions (grey graphs in background).

fraction, however, was not integrated in the mean robust endmember compilation (compare Fig. $2 \mathrm{a}$ and b), because it was only present in two samples explaining only $1 \%$ of the mean total variance, which furthermore resulted in a poorer unmixing of rEM1 and rEM2 modes. Adding the set of modern lake surface samples (Dietze et al., 2012) to the Donggi Cona data 

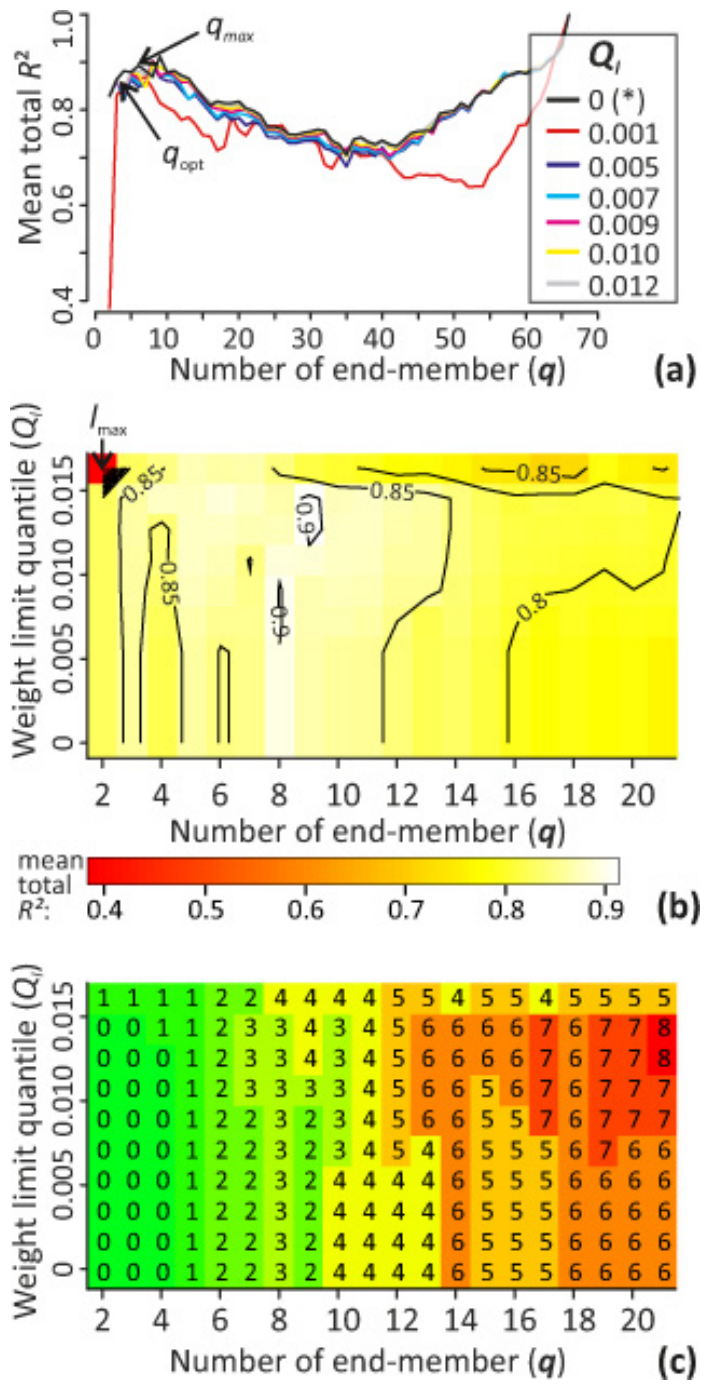

Fig. 3. Example how boundary parameters were defined for all similarly-likely model runs using the Nam Co core grain-size data set. (a) $Q-R_{\text {mean }}^{2}$ plot after Dietze et al. (2012) for selected weight quantiles $(\boldsymbol{l})$ and numbers of end members $(\boldsymbol{q})\left(q_{\text {opt }}\right.$ at the inflection point after Weltje and Prins (2007); $q_{\max }$ at the first local maximum); (b) a 3-D pattern of the $Q-R_{\text {mean }}^{2}$ plot including an example sequence of $10 \boldsymbol{l}$ between 0 ( $^{*}$ after Miesch, 1976, corresponds here to $l_{\mathrm{opt}}$ ) and the numerical maximum of $\boldsymbol{l}$ and the first $20 \boldsymbol{q}$ that resulted in different end-member models, for which (c) shows the number of overlapping modes (only zero overlaps were taken into account for robust similarly-likely model runs).

set resulted in similar end-member composition for the core data indicating the reliability and robustness of the results (not shown).

The grain-size distributions of TOC11/4, TOCall and Targo Xian were composed of five rEM explaining 89.1, 87.6 , and $85.0 \%$, respectively, of the mean total variance of the original data sets. The rEM modes of the individual Taro Co cores were also present at the same grain-size fractions and with similar shape in the rEM of both cores (Fig. 2,

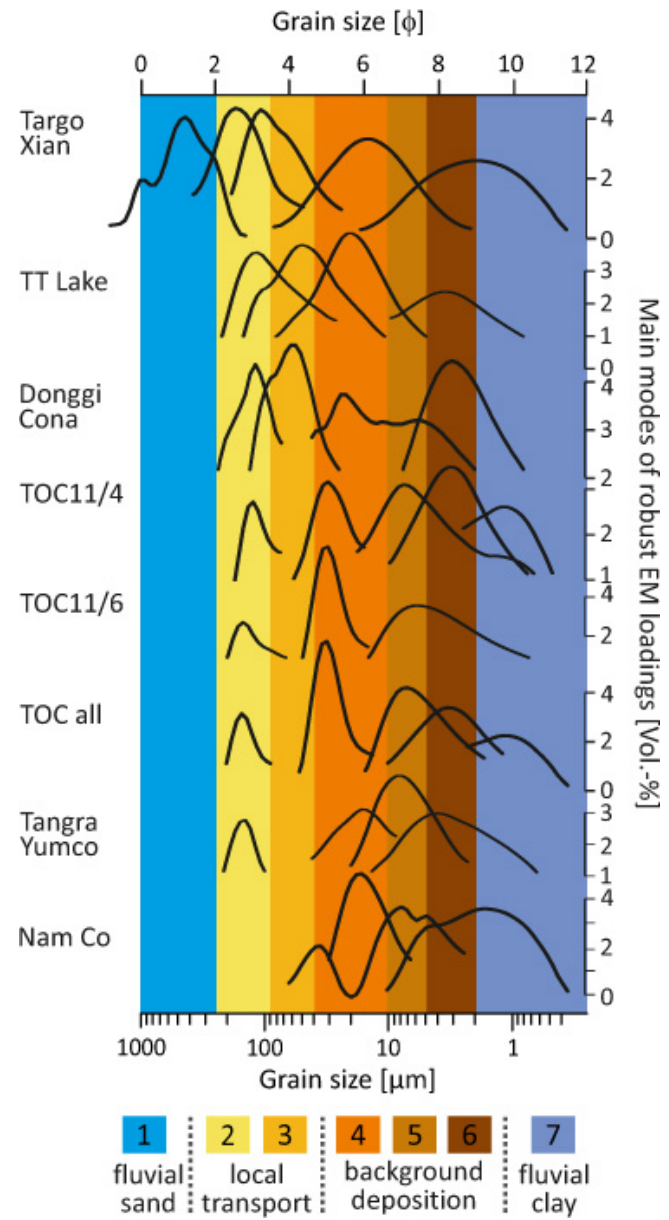

Fig. 4. Main modes of mean robust end-member loadings grouped as typical sediment transport modes. Numbers indicate sediment types: 1 - fluvial sand, 2 - aeolian sand, 3 - coarse local dust, 4 coarse regional dust, $5 / 6$ - remote dust, 7 - fluvial clays (see text for details).

TOC11/4 and TOC11/6 vs. TOC all). However, the location of the Taro Co core sites played a role in the number of rEM $(\boldsymbol{q})$ with higher $\boldsymbol{q}$ at TOC11/4 compared to the distal site of TOC11/6 (Table 3).

\section{Characteristics and origin of the robust grain-size end members}

\subsection{Preliminary considerations}

Modelled robust end members showed distinct grain-size modes that can be grouped across the Tibetan Plateau, independent of the length of the individual sedimentary sequence. Similar modes were found as typical components in multimodal grain-size data of sediments in the Donggi Cona catchments (Stauch et al., 2012; Dietze et al., 2013). They reflect known distributions of fluvial and aeolian sediment 
types similar to those investigated at their characteristic depositional environments (Sun et al., 2002, 2007; Vandenberghe, 2013). To better understand the relation between grain sizes, transport mode and depositional environment some climatic parameters, the mean wind velocity, direction and shear velocity across the Tibetan Plateau for the four seasons are presented in Fig. 5 and Table 4. The seasonality in the wind patterns is evident: high velocities and spatially consistent patterns are observed in winter, whereas in summer, a marked cyclonic circulation (the "Tibetan Low") characterizes the surface wind fields, with larger differences between the studied lakes. Averaged across all areas above 3000 ma.s.l. highest shear velocities $\left(>0.8 \mathrm{~m} \mathrm{~s}^{-1}\right)$ occur in winter and spring, whereas autumn is the calmest time of the year (Fig. 5, Table 4a). Regionally, highest wind velocities occur more to the west and south of the Tibetan Plateau along the main track of the westerlies and the highest mountain ranges. Hence, more wind shear velocity extreme events $\left(>1.2 \mathrm{~m} \mathrm{~s}^{-1}\right)$ that could transport coarser grains occur along the climatic gradient from the westernmost lake Taro Co to Nam Co and are less frequent at lake Donggi Cona (Table 4b).

For the interpretation in terms of typical Tibetan-wide sediment transport and depositional processes, robust grainsize end members are associated with climatic conditions including Tibet-wide lake ice phenology (Kropáček et al., 2013), precipitation and snow/glacial melt (Maussion et al., 2013), the latter being the main triggers of fluvial sediment transport. For simplicity and following the experimental results of Tsoar and Pye (1987) for quartz sphere transport at mean Tibetan shear velocities rEMs were grouped in terms of transport modes with modes $>90 \mu \mathrm{m}$ being primarily transported locally by saltation. Grain-size rEM between 40 and $90 \mu \mathrm{m}$ represent local dust sediment transport, whereas grains $<40 \mu \mathrm{m}$ represent regional plateau-wide and remote dust flux in long-term suspension. The finest rEM with modes $<2 \mu \mathrm{m}$ as a special case might represent local fluvial clays.

\subsection{The "local transport" end members}

\subsubsection{Fluvial sands}

At the terrestrial site Targo Xian the coarsest rEM of all sites was found with a mode between 250 and $600 \mu \mathrm{m}$ in the medium to coarse sand. It had a minor mode at $1 \mathrm{~mm}$ and a shoulder at $\sim 280 \mu \mathrm{m}$ with a maximum at $450 \mu \mathrm{m}$. It contributed $13.7 \%$ to the mean grain-size variance (Fig. 2). Its scores were high in the Targo Xian lithological unit, where also gravels were found. Tentatively, this rEM also contributed to the small TT Lake but there it explained only $1 \%$ of the grain size.

This rEM indicates a general transport mechanism delivering particles to the site by rolling and saltation in highenergy fluvial suspension (Tsoar and Pye, 1987; Fig. 4). Flu-
Table 4. Frequency on an hourly basis of wind shear velocities events from the High Asia Reanalysis (HAR) calculated as (a) average across the Tibetan Plateau for different seasons (winter, DJF, spring, MAM, summer, JJA, and autumn, SON) and (b) all-year average across the four largest lake catchments.

\begin{tabular}{|c|c|c|c|c|}
\hline $\begin{array}{l}U^{*} \\
{\left[\mathrm{~ms}^{-1}\right]}\end{array}$ & DJF & MAM & JJA & SON \\
\hline$\geq 1.2$ & $0.17 \%$ & $0.20 \%$ & $0.01 \%$ & $0.05 \%$ \\
\hline$[0.8,1.2]$ & $3.55 \%$ & $4.34 \%$ & $1.05 \%$ & $1.70 \%$ \\
\hline$[0.5,0.8]$ & $20.64 \%$ & $23.10 \%$ & $17.99 \%$ & $16.02 \%$ \\
\hline$[0.2,0.5]$ & $46.72 \%$ & $45.83 \%$ & $54.56 \%$ & $46.92 \%$ \\
\hline$<0.2$ & $28.92 \%$ & $26.53 \%$ & $26.39 \%$ & $35.31 \%$ \\
\hline
\end{tabular}

\begin{tabular}{|c|c|c|c|c|}
\hline \multicolumn{5}{|c|}{ (b) Regional frequency of wind shear velocities events } \\
\hline $\begin{array}{l}U^{*} \\
{\left[\mathrm{~ms}^{-1}\right]}\end{array}$ & Donggi Cona & Nam Co & Tangra Yumco & Taro Co \\
\hline$\geq 1.2$ & $0.04 \%$ & $0.20 \%$ & $0.31 \%$ & $0.33 \%$ \\
\hline$[0.8,1.2]$ & $3.12 \%$ & $5.90 \%$ & $5.00 \%$ & $6.94 \%$ \\
\hline$[0.5,0.8]$ & $24.75 \%$ & $31.60 \%$ & $24.86 \%$ & $28.97 \%$ \\
\hline$[0.2,0.5]$ & $54.56 \%$ & $46.72 \%$ & $45.83 \%$ & $46.92 \%$ \\
\hline$<0.2$ & $25.56 \%$ & $17.59 \%$ & $21.69 \%$ & $17.74 \%$ \\
\hline
\end{tabular}

vial sediments can be of multimodal character depending on sediment load and current velocities, typically showing coarse modes between 200 and $400 \mu \mathrm{m}$ (Sun et al., 2002) or even coarser. Compared to sediment delivered through aeolian transport fluvial deposits are generally coarser and poorly sorted (Tsoar and Pye, 1987). In modern surface sediments and in on-shore high-stand sediments of lake Donggi Cona this mode was also present in small amounts $(\sim 6$ $10 \%$ ) with a similar mode shape. There, it was interpreted as fluvial and littoral transport, because it appeared only in the fluvial and wave-sorted high-stand facies (Dietze et al., 2012, 2013). Furthermore, it was the prominent mode of typical alluvial fan deposits in an aeolian-fluvial sedimentsoil sequence in other environments (e.g. in Europe, Pendea et al., 2009). The absence of fluvial sands in the lacustrine sediments of the larger lakes might be related to the distance to the shore (and to inflows) and the immediate settling, when fluvial transport energy drops at the lake shore. Fluvial transport occurs in spring and summer, when the ground has thawed and most precipitation occurs (Maussion et al., 2013).

\subsubsection{Aeolian sands}

The coarsest rEM in the larger lake settings had a mode in the fine to very fine sand between 90 and $250 \mu \mathrm{m}$. It had a very similar mean shape and maximum position at $\sim 150 \mu \mathrm{m}$ at Taro Co and at Tangra Yumco (Fig. 2a). The mode was finer at Donggi Cona and TT Lake (maximum at $120 \mu \mathrm{m}$ ). It explained $\sim 20 \%$ of variance at the small TT Lake and $12.5 \%$ at the TOC $11 / 4$ site. It contributed much less to the sediment 

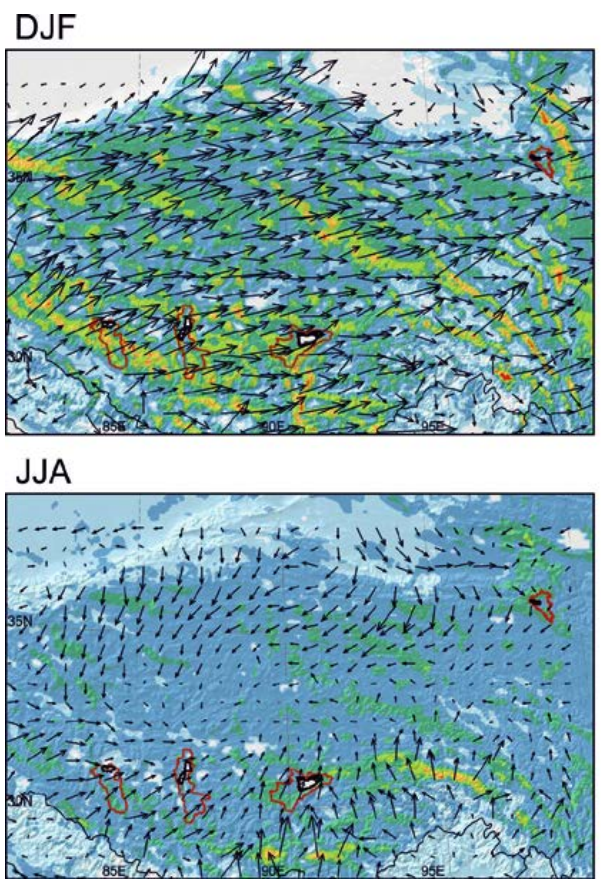

MAM

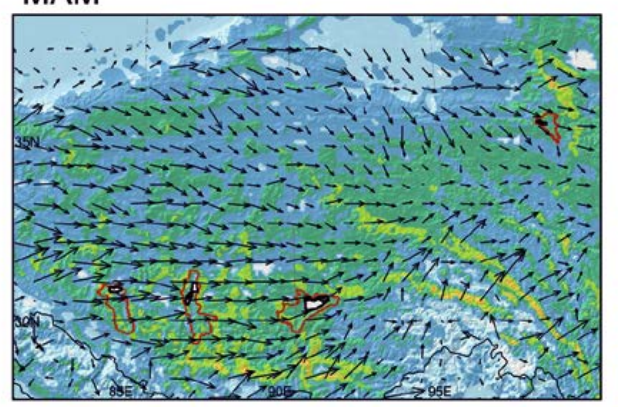

\section{SON}

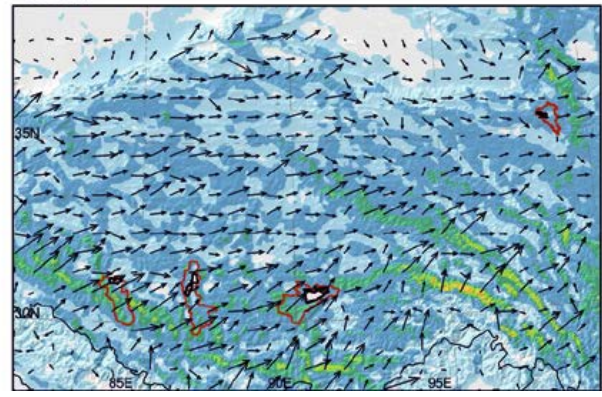

$\mathrm{m}^{\star} \mathrm{s}^{-1}$

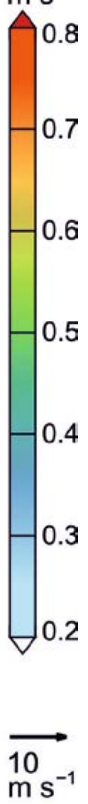

Fig. 5. Mean shear velocities ( $U^{*}$, colour scale) and wind direction and speed (arrows, plotted every 6th grid point) for winter (DJF), spring (MAM), summer (JJA) and autumn (SON) extracted from the High Asia Reanalysis (HAR). The studied catchments are delimited in red.

at the more distal, deep water positions of Tangra Yumco and Taro Co (TOC11/6). At Targo Xian there were two rEM modes in this range (Figs. $2 \mathrm{~b}$ and 4 ). One was well-sorted and coarser between 250 and $100 \mu \mathrm{m}$ with its maximum at $194 \mu \mathrm{m}$. It made up one third of the site's grain-size variance. The second was a relatively broad, but very robust mode in the very fine sand between 50 and $150 \mu \mathrm{m}$ with a maximum at $92 \mu \mathrm{m}$ and a secondary shoulder at $60 \mu \mathrm{m}$. It explained $21 \%$ of the Targo Xian grain-size variance (Fig. 2). In general, this mode was relatively heterogeneous and less robust (large standard deviation, Fig. 2b) than other rEM modes.

This rEM may be associated with a local transport of rolling and saltation by strong surface winds. The same size fractions dominated in dark laminae of lake Kuhai (Fig. 1, Mischke et al., 2009) and were composed of subangular mineral grains indicative of wind transport. In modern Donggi Cona surface sediments this end member occurred randomly in all samples and was interpreted as sands moving on the frozen lake surface (Dietze et al., 2012). Hence, a (partial) freezing of the lake from the shore is required to contribute sand to more distal positions, also by drifting ice containing trapped sediment. However, at larger lakes only little sandy material can reach the more distal locations because ice traps coarse particles in cracks and occasional snow cover (Nedell et al., 1987), which would explain the lack of this end member in the Nam Co core.

The transport of "aeolian sands" (Sun et al., 2002) on frozen lakes can be associated with very strong, episodic winds that are dominant especially during winter and early spring times on the Tibetan Plateau from westerly and northerly directions (Fig. 5). This transport is most effective during winter and spring storms with mean shear velocities of $>0.8 \mathrm{~m} \mathrm{~s}^{-1}$ and grains $>90 \mu \mathrm{m}$ could even go into short-term suspension (Tsoar and Pye, 1987; Table 4). A brownish stained ice surface was observed several times at Donggi Cona and lake Kuhai (Fig. 6); especially during spring ice break-up (Mischke et al., 2009). Its mode heterogeneity might be related to different grain inventories at the littoral sources, for example, dune fields and local river beds (Stauch et al., 2012). It fits well with the aeolian sediment type 1.a described by Vandenberghe (2013), who pointed out its local character.

At the terrestrial Targo Xian site the subdivision into two rEM (Fig. 2a) that occurred in samples of different age (not shown) could indicate a systematic change in transported material and/or wind field. The well-sorted coarser rEM can be related to dune formation (Tsoar and Pye, 1987; Sun et al., 2002). However, the finer rEM was finer than typical dune sediment and it might even point to a different process: reworking of sands of different sources by low-energy unconfined alluvial flow (sensu North and Davidson, 2012) as found in Donggi Cona high-stand sediments (Dietze et al., 2013). 


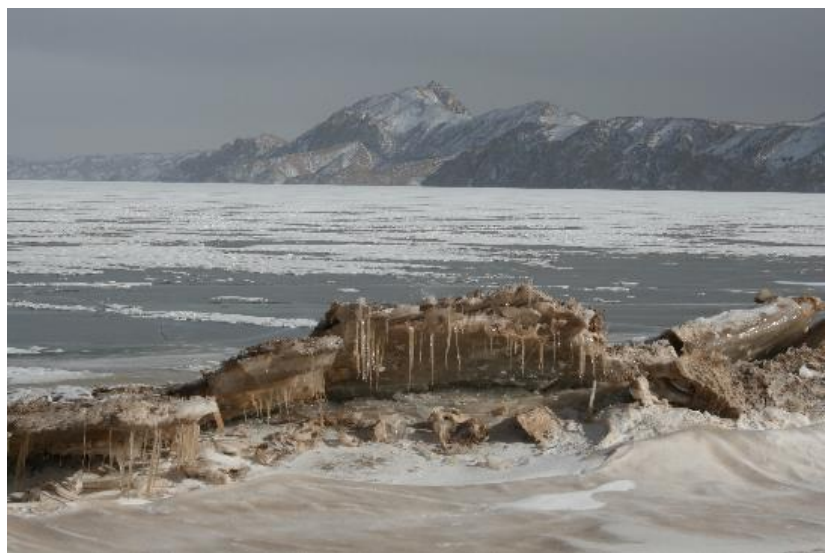

Fig. 6. Sediment trapped in lake ice at lake Donggi Cona (Photo: B. Diekmann, February 2007).

\subsubsection{Coarse local dust}

At the boundary of very fine sand and coarse silt a further rEM had a mode between 40 and $90 \mu \mathrm{m}$ with maxima in the TT Lake and Donggi Cona data sets at 53 and $63 \mu \mathrm{m}$, respectively. It was only present at these two sites and had a secondary shoulder $\sim 100 \mu \mathrm{m}$ (Fig. 2) indicating that saltation and/or high shear velocities might still be important. This rEM was similar to the local dust end member in the lake Donggi Cona surface samples, where it contributed $\sim 17 \%$ to the total sediment composition (Dietze et al., 2012) - the same contribution as to TT Lake sediments.

In the catchment of lake Donggi Cona it was the dominant grain-size fraction in sandy loess (Stauch et al., 2012) and constituted an end member in onshore lake high-stand sediments interpreted as local dust (Dietze et al., 2013). The sediment represented by this rEM was probably transported from proximal sources as coarse local dust that was lifted into near-surface, short-term suspension clouds, when shear velocities between 0.2 and $0.8 \mathrm{~m} \mathrm{~s}^{-1}$ prevailed (Tsoar and Pye, 1987). Although these shear velocities are observed in all seasons (Fig. 5, Table 4), sediment needs to be available in the catchments as in periods of unfrozen soil and limited vegetation cover during spring and early summer. Sun et al. (2003) found the same grain-size modes in presentday dust deposited after major spring-summer dust storms on the Chinese Loess Plateau. On the Tibetan Plateau the sandy loess probably has its source in local rivers, sand sheets at the slopes, periglacial and glaciofluvial debris (Stauch et al., 2012). It corresponds to the coarsest-grained loess fraction distinguished by Vandenberghe (2013; i.e. sediment type 1.b.3, also associated with loess deposited during high wind intensities at the Loess Plateau).

\subsection{The "background deposition" end members}

\subsubsection{Coarse regional dust}

A rEM present in all studied Tibetan lake sediment records had modes between 10 and $40 \mu \mathrm{m}$, with broader maxima at $17 \mu \mathrm{m}$ (Nam Co and Tangra Yumco) and $21 \mu \mathrm{m}$ (TT Lake) (Figs. 2 and 4). The mode was very well sorted and symmetrical at Taro Co (TOC) between 23 and $42 \mu \mathrm{m}$ with a maximum at $33 \mu \mathrm{m}$. It contributed almost $50 \%$ of the sediment to the deep position of this westernmost lake (TOC11/6). At Targo Xian, rEM 4 (Fig. 2b) had a slightly finer, but much broader mode with a maximum at $11.8 \mu \mathrm{m}$. Donggi Cona core sediments consisted of a very broad mode of rEM 3 between 5 and $40 \mu \mathrm{m}$ with a maximum at $22 \mu \mathrm{m}$ (Fig. $2 \mathrm{~b}$ ).

The grain sizes of this rEM are similar to the loess described from Donggi Cona catchment with a suggested source area in the Qaidam Basin, $\sim 100 \mathrm{~km}$ away (Stauch et al., 2012) - a similar distance as reported from a provenance study of Romanian loess of the same size (Pendea et al., 2009). Particles of these sizes can easily be captured on water surfaces, but also in snow and ice or on (vegetated) slopes (Goossens, 2005; Stauch et al., 2012), which was the suggested depositional process for the robust "remote dust" grain-size end member in Donggi Cona surface and lake high-stand sediments (Dietze et al., 2012, 2013). The typical Tibetan loess was slightly coarser in the Yarlong Zangbo River valley south-east of Nam Co compared to the Donggi Cona loess at the north-eastern Tibetan Plateau (20-44 $\mu \mathrm{m}$, Sun et al., 2007 compared to 10-30 $\mu \mathrm{m}$, Stauch et al., 2012).

This rEM represents the size fractions of standard loess that can keep in short-term suspension in the lower atmosphere (Tsoar and Pye, 1987). It could episodically be transported over larger distances and longer time compared to coarser fractions (Pendea et al., 2009; Stauch et al., 2012). Particles $<20 \mu \mathrm{m}$ can stay in suspension for days during storms with mean shear velocities $>0.3 \mathrm{~m} \mathrm{~s}^{-1}$ (Tsoar and Pye, 1987) that occur throughout the year, but are less likely during autumn (Fig. 5). Hence, this mode should be associated with large-scale, plateau-wide dust storms that deposit coarse regional dust discontinuously during dry periods (e.g. during Tibetan spring storms before the onset of the monsoonal rain season). It can be transported occasionally also in summer times by cyclonic circulations to the northern and western Tibetan Plateau with northeasterly winds (Chen et al., 2013). This rEM represents a combination of the silt sediment types 1.b.2 and 1.b.3 of Vandenberghe (2013).

If transported by wind alone, the mode would be well sorted as in the case of Taro Co sediments (Fig. 4). However, it is also likely that loess was reworked from the onshore slopes (e.g. by unconfined overland flow), as observed in summers 2006 and 2009 at lake Donggi Cona, which might also be likely at the terrestrial site Targo Xian. These sediment-saturated flows enter the lakes as density over- or interflows (Sturm and Matter, 1972) and can be distributed 
by water currents within the lake also to more distal sites. This would not alter the grain-size mode because the aeolian signature can still be well preserved (Vandenberghe, 2013), especially when the fluvial transport ways were short and no further sorting occurred. A comparison of terrestrial sheetflood and loess surface samples of the Donggi Cona catchments showed similar grain-size distributions supporting this assumption (Dieckmann and Dietze, unpublished data). However, the environmental conditions and implications for using this $\mathrm{rEM}$ as a proxy in palaeoclimate studies would be slightly different for direct aeolian deposition or reworking by overland flow.

\subsubsection{Remote dust}

A rEM in the very fine silt had a mode between 5 and $10 \mu \mathrm{m}$, with maxima at 6.2 and $7.6 \mu \mathrm{m}$ at Taro Co (finer at the deeper location) and $8.2 \mu \mathrm{m}$ at lakes Tangra Yumco and Nam Co (Fig. 4). At Nam Co it constitutes the main mode of the multimodal rEM sediment (Kasper et al., 2012). It was absent in the small TT lake, but could be integrated in Targo Xian rEM 4 (Figs. 2 and 4), which consisted mainly of the fine short-term suspension end member and seemed to be a reworked loess. The more prominent robust clay end member that appeared all over the Tibetan Plateau had a mode between 2 and $5 \mu \mathrm{m}$, with maxima at 2.4 (Nam Co), $~ 3.4$ (TT Lake, Donggi Cona, Taro Co), and $4.2 \mu \mathrm{m}$ in lake Tangra Yumco (Fig. 4). Light laminae of subspherical particles $\sim 4 \mu \mathrm{m}$ represented this mode in lake Kuhai (Fig. 1), although their alteration with darker, coarser laminae could not be related to seasonal or annual cycles (Mischke et al., 2009).

These rEM represent the finest aeolian sediments distinguished by Vandenberghe (2013; type 1.c.2: 2-10 um). According to Sun et al. (2004) particles of the size fractions represented by both rEM can be transported over large distances $(1000-2000 \mathrm{~km})$ in atmospheric levels up to $7 \mathrm{~km}$ high. Hence, these rEM grain-size modes represent a continuous background dust deposition all year long (Sun et al., 2004; Vandenberghe, 2013) and can be traced even in the North Pacific (Rea, 1994). On the Tibetan Plateau the remote dust is assumed to originate mainly from the northwestern and northern Central Asian deserts transported by the highlevel westerly jet stream in winter and episodic northerly winds in summer time along a main transport route from northwest to southeast (Fig. 5; Zhang et al., 2001; Sun et al., 2002; Stauch et al., 2012; Chen et al., 2013).

In contrast to dry deposition of modern Australian dust $(20-40 \mu \mathrm{m})$ considerably finer grains $(3.5-15 \mu \mathrm{m})$ were accumulated by wet deposition (Hesse and McTainsh, 1999). However, Zhang et al. (2001) showed that wet deposition accounted for less than $10 \%$ of the total Tibetan dust deposition. Hence, dry deposition can be assumed as the major depositional process behind these rEMs. Dry remote dust can also be trapped directly on the water or ice surface of the lakes. These fractions need a calm water column to set- tle down to the lake bottom, which is probably only possible when the lakes are partially or completely frozen during winter (Francus et al., 2008).

The two background dust rEM were separated for different reasons: (a) the lake size could play a role - the finest-silt rEM occurred only in the larger lakes, which may be due to different sediment trapping properties than in small lakes and on land (Goossens, 2005), (b) the steepness of the catchment close to the lake could influence local luv-lee and katabatic wind dynamics (Fig. 1), and/or (c) these two rEM indicate two different source regions, high-level wind directions and wind speeds that could change seasonally. The finest-silt rEM can be compared to modes of 5-8 $\mu \mathrm{m}$ of the Chinese Loess Plateau red clays (Vandenberghe, 2013) deposited under intense winter monsoon conditions related to the Siberian High similar to Quaternary loess (Vandenberghe et al., 2004), whereas a finer Red Clay fraction $<5.5 \mu \mathrm{m}$ representing the clay $\mathrm{rEM}$ is assumed to reflect more westerly wind directions from its isotopic signatures (Vandenberghe et al., 2004). Hence, these two background dust end members should be discussed together with other mineralogical or geochemical proxies to distinguish different sources and wind directions in future palaeoenvironmental discussions.

An overprint of the main transport mode similar to other aeolian sediments could be occasional summer fluvial and alluvial flow in the catchment that erode and rework the slope deposits together with soil clay aggregates. Hence, in Donggi Cona surface and lake high-stand sediments this rEM was interpreted more generally as "suspension" load (Dietze et al., 2012) and associated with high lake levels (Dietze et al., 2013). In the context of a multi-proxy approach (Kasper et al., 2013) characteristic grain-size distributions at lake Nam Co were attributed to certain lake levels. Grain-size distributions with the secondary mode (rEM 2, Fig. 2b) were interpreted as representative for a lake level rise (Kasper et al., 2012).

\subsection{Fluvial clay}

The finest rEM had a modal size of $0.7-2 \mu \mathrm{m}$ and could only be found at lake Taro Co as an individual rEM with a maximum at $\sim 1.2 \mu \mathrm{m}$ (TOCall and TOC11/4; Fig. 4). It explained $22 \%$ of the grain-size composition in the $68 \mathrm{~m}$ water-depth core TOC11/4 (Fig. 2) and was absent in the deeper position. It may have contributed to the broader clay mode that dominated the lowermost lithological unit in the record of lake Nam Co, which was deposited during times of a higher lake level (Kasper et al., 2012). At Targo Xian it was part of a broad clay end member with a mode between 0.7 and $5 \mu \mathrm{m}$ (maximum at $1.7 \mu \mathrm{m}$ ).

A likely transport mechanism is fluvial input of clay minerals from weathered catchment soils. At Taro Co they could be washed into the $\sim 160 \mathrm{~km}$ long river course from the south (Fig. 1) and from the nearby slopes during extreme precipitation events. At palaeo-lake Targo Xian and Nam Co 
the broad and very fine rEM dominated only the lowermost parts of the stratigraphies that were associated with higher lake stands (Kasper et al., 2012). This would indicate wetter times, when also weathering of soils and the amount of runoff were higher. Depending on lake stratification and water currents, finest clay minerals with a size $<1 \mu \mathrm{m}$, were transported farthest into lake Donggi Cona compared to other coarser clay minerals (Opitz, unpublished data).

Clays can only reach the lake during summer runoff and remain in the water column as long as settling is possible by ice cover of the lake. Freezing of lakes normally starts in the protected bays, but also depends on wind and wave activity (Kropáček et al., 2013). In comparison with the other large lakes of this study, Taro Co had the lowest duration of complete ice cover in the analysis of modern day ice phenology (Kropáček et al., 2013), although no causes were discussed by the authors. Hence, it is more likely that the shallow areas freeze and allow an earlier settlement of the finest particles. Over the deepest lake parts surficial wind-induced currents would still prevent fine material from settling. Another reason might be the west-east extension of the Taro Co basin (Fig. 1), which allows the greatest fetch along the dominant westerly wind direction (Fig. 5). Hence, surface water currents probably bring particles predominantly to the eastern bay.

Furthermore, this size range $(<2 \mu \mathrm{m})$ was also found in high percentages (up to $74 \%$ of total dust deposits) on high Tibetan mountain ranges, where it was trapped in glacier ice (Wu et al., 2010) indicating an aeolian origin of the material from the upper troposphere. The occurrence of grain-size modes between 0.8 and $2 \mu \mathrm{m}$ in Greenland ice cores (Ruth et al., 2003) suggests a global distribution via long range transport and also that potential source areas could be much farer away from Tibet than for the regional background dust. It could be deposited in the lakes in aggregated forms from direct dust deposition on water and disperse in the water column to later settle down under calm conditions. If the contributions from the finest, long range dust would be comparable to other transport modes, there would be some signal visible in all lake systems and not only at lake Taro Co (especially at the shallow site). Hence, the finest background dust does not seem to explain the sediment source of this rEM.

Therefore, it is much more likely that the robust clay end member results from pedogenic clay that was fluvially transported to the lake. It seems to be of local origin, but may include the finest parts of remote dust. Both fractions settle only when the lake surface is ice-covered.

\subsection{The relative contribution of grain-size end members}

Assuming the reliability of the rEM interpretation, the relative contributions of the three major sediment transport processes can be estimated in a first approach using the sum of the explained variances of the mean rEM in \% (Fig. 2b) grouped into fluvial (sand and clay), local dust and remote dust for each core (Fig. 4). Accordingly, these processes contribute to the sediment accumulation in the studied Tibetan lakes as follows: (a) fluvial processes induced by precipitation and glacier or snow melt contribute $18.8 \pm 4.5 \%$ (Targo Xian rEM 1, TOC11/4 and TOCall rEM 5; mean \pm standard deviation from Fig. 2b), (b) short-range local and regional dust $42.3 \pm 13.7 \%$ and (c) the remote dust $50.9 \pm 10.5 \%$. The broad and ambiguous rEM 5 (Targo Xian), rEM 3 (Donggi Cona) and Nam Co rEM 2 and 3 were not included in this calculation. Hence, fluvial sands and clays from the catchment could make up less than a quarter of total detrital sediment components in this region, whereas aeolian sedimentation seems to be the dominant detrital sediment input in Tibetan lakes and catchments (the dominant aeolian signature appears to be preserved despite subsequent short-term fluvial/alluvial reworking). In comparison with climatic conditions (Fig. 5), sediment availability and deposition seem to vary seasonally.

Similarly, Wu et al. (2010) found that there was a 5.6 times higher winter dust deposition on high-altitude Dasuopu Glacier compared to summer times, although a differentiation after grain size was not provided. In comparison with more humid regions, aeolian processes are a key factor in the Tibetan sediment cycle similar to other desert regions. However, total annual dust deposition rate on the Tibetan Plateau (local plus remote sources; dry plus wet deposition) was only a third of that in Chinese deserts in a study of dust fluxes during non-dust storm days in 1993 and 1994 (Zhang et al., 2001).

\subsection{Limitations}

Although robust grain-size end members seem to be comparable across the Tibetan Plateau, some limitations have to be considered. First, end-member modelling of multimodal grain-size distributions still has some numerical problems concerning unexplainable secondary modes that are not yet fully understood. For example, the secondary mode in Nam Co rEM 2 could either be an artifact or reflect a depositional process that integrated different grain-size classes (e.g. glacial processes, Diekmann, 1990). However, the performance of EMMA was never tested using classical diamicts.

Second, a likely contribution of authigenic diatom production has to be taken into account. The preservation, distribution and importance of diatoms in most Tibetan lakes is generally low and Tibetan diatom records are sparse (Gasse et al., 1991). Therefore, it was not considered to be an important factor during pretreatment of the studied samples. However, temporal shifts in the silica limitation can alter diatom abundance and thus the grain-size distributions of the sediment.

Third, the relationship between grain-size distributions (i.e. all end members) and transport processes depend on further factors, for example, shear velocities related to land cover and surface roughness, (already sorted) sediment sources, sediment concentrations, pathways and carrying 
capacities of the transport medium (Tsoar and Pye, 1987; Vandenberghe, 2013). Sediment sorting considers also further grain characteristics like grain shape and density that are related to the respective grain source material. Grains, especially cohesive fine silts and clays, may enter the transport medium in the form of soil or sediment aggregates or can form floccules in water. Hence, fine material would not necessarily disperse into individual particles in the lake (Schieber et al., 2007) like during pretreatment for laser particle size analysis. However, after a long transport in suspension either in rivers or in lake currents the finest material would settle down individually under very calm conditions and form clay caps as observed in clastic varves after ice cover (Cockburn and Lamoureux, 2008; Francus et al., 2008).

Finally, it is difficult to compare Tibetan lake sedimentation with other studies (e.g. from arctic or alpine lakes), where sedimentation monitoring strategies helped to better assess lacustrine deposition (Cockburn and Lamoureux, 2008; Francus et al., 2008; Kämpf et al., 2012). First of all, seasonal laminations are rare in the Tibetan lakes (Chu et al., 2011), and a considerable effort would be needed to link them to sediment trap and meteorological observations at this remote site. Second, in the high-altitude Tibetan Plateau the amount of snow and snow melt is small due to low winter precipitation (Maussion et al., 2013), high insolation and sublimation compared to other permafrost regions (French, 2007). Greatest runoff and peak precipitation occur during summer and are associated with local convection, cyclonic circulation and thunderstorms (Maussion et al., 2013). They can cause local overland flows that erode slope material complicating the palaeoclimatic interpretation of certain grainsize fractions being deposited at a certain time.

\section{Conclusions}

Sediment transported and sorted along different pathways is deposited as mixed allochthonous material on the bottom of lakes. Modelling and "unmixing" grain-size end members can be an attractive, quantitative alternative to classic approaches of grain-size data evaluation that help to better understand past environmental changes.

In this study, different lake systems that store sediments from various time spans, depositional environments and catchment configurations were investigated. Grain-size end member modelling of Tibetan lake sediments resulted in statistically robust loadings related to the initial grain-size sorting processes. Robust grain-size end members were interpreted as sedimentation processes using links to local catchment configurations and the modern climatic background (i.e. lake ice phenology, precipitation). To our knowledge, wind-shear data was analysed for the first time on the Tibetan Plateau and helped to better understand aeolian processes. Most sedimentation processes are consistent across the Tibetan Plateau. Assessing the relative contributions of sediment transport mechanisms local (catchment-wide), regional (plateau-wide) and remote aeolian transport account for most of the clastic sedimentation in Tibetan lakes, whereas the direct fluvial component is of minor importance. Driven by changes in atmospheric circulation, processes of sediment transport and deposition may differ between seasons, i.e. aeolian transport dominates during times of high wind speeds and shear velocities. Future work will link these grain-size-process relationships with the past (using end-member scores, that is, rEM composition in depth/time, Dietze et al., 2012) to assess changes in the process contributions in space and time and facilitate the palaeoenvironmental interpretation of lake sediment archives - a concept that is transferable to other sediment archives and regions of the world.

Since the interpretation of the robust grain-size end members can be seen in general terms of transport energies and agents it is not restricted to certain time periods, lacustrine records and/or to the Tibetan Plateau. For future palaeoenvironmental reconstructions, robust grain-size end members can provide valuable, independent, and quantitative proxies of typical sedimentation processes that are related to past or present environmental and climatic conditions in many other settings. However, grain-size end members should be seen as a continuum and grain-size boundaries that were used to group them are far from being fixed. The background conditions for sediment availability, transport and deposition may vary in time in concert with regional changes in climate (precipitation, wind, ice phenology), or local changes of human activity (affecting land cover; Schlütz and Lehmkuhl, 2009) and tectonics (affecting basin and catchment configuration; Dietze et al., 2013). Hence, sedimentation end members might change their main mode positions and their relative importance, when certain time slices, regions or different types of sediment archives (e.g. loess, dune sequences) are studied individually in a high resolution.

To better assess their meaning robust grain-size end members should be compared with other proxies, for example, micropalaeontological, geochemical and mineralogical data, as well as with all available information from basin and catchment morphologies and the regional climate system. The transferability of the information that robust grain-size end members can provide should be tested in similar studies in other climatic and environmental settings. When considering that end members are not a stand-alone proxy and special local end members might occur, a high transferability of the method and helpful information on past sedimentation processes related to (palaeo-)environmental change are gained.

Acknowledgements. This study integrates several groups of the German Research Foundation (DFG) priority programme "Tibetan Plateau: Formation-Climate-Ecosystems" (SPP 1372). E. Dietze thanks T. Swierczynski, U. Kienel, P. Schulte, and M. Dietze for the fruitful discussions. C. Kirchner is acknowledged for grain-size analyses in Jena. K. Henkel would like to thank the Max 
Planck Society and T. Kasper the Carl Zeiss Foundation for the funding of their PhD positions. The HAR was produced within the WET project (code 03G0804A), financed by the German Federal Ministry of Education and Research (BMBF) Program "Central Asia - Monsoon Dynamics and Geo-Ecosystems". We further thank Keely Mills, Jef Vandenberghe and an anonymous reviewer for helpful suggestions that improved the manuscript.

The service charges for this open access publication have been covered by a Research Centre of the Helmholtz Association.

Edited by: K. Mills

\section{References}

Bartholdy, J., Christiansen, C., and Pedersen, J. B. T.: Comparing spatial grain-size trends inferred from textural parameters using percentile statistical parameters and those based on the loghyperbolic method, Sediment. Geol., 202, 436-452, 2007.

Blott, S. J. and Pye, K.: GRADISTAT: a grain size distribution and statistics package for the analysis of unconsolidated sediments, Earth Surf. Proc. Land., 26, 1237-1248, 2001.

Böhner, J.: General climatic controls and topoclimatic variations in Central and High Asia, Boreas, 35, 279-295, 2006.

Chen, S., Huang, J., Zhao, C., Qian, Y., Leung, L. R., and Yang, B.: Modeling the transport and radiative forcing of Taklimakan dust over the Tibetan Plateau: A case study in the summer of 2006, J. Geophys. Res., 118, 797-812, 2013.

Chu, G., Sun, Q., Yang, K., Li, A., Yu, X., Xu, T., Yan, F., Wang, H., Liu, M., Wang, X., Xie, M., Lin, Y., and Liu, Q.: Evidence for decreasing South Asian summer monsoon in the past 160 years from varved sediment in Lake Xinluhai, Tibetan Plateau, J. Geophys. Res., 116, D02116, doi:10.1029/2010JD014454, 2011.

Cockburn, J. H. and Lamoureux, S.: Inflow and lake controls on short-term mass accumulation and sedimentary particle size in a High Arctic lake: implications for interpreting varved lacustrine sedimentary records, J. Paleolimnol., 40, 923-942, 2008.

Cohen, A. S.: Paleolimnology: the history and evolution of lake systems, Oxford University Press, New York, 500 pp., 2003.

Diekmann, B.: Granulometry and sand grain morphoscopy of alpine glacial sediments, Zbl. Geo. Pal., Teil 1, 1989, Heft 9/10, 14071421, 1990.

Dietze, E., Wünnemann, B., Diekmann, B., Aichner, B., Hartmann, K., Herzschuh, U., IJmker, J., Jin, H., Kopsch, C., Lehmkuhl, F., Li, S., Mischke, S., Niessen, F., Opitz, S., Stauch, G., and Yang, S.: Basin morphology and seismic stratigraphy of Lake Donggi Cona, north-eastern Tibetan Plateau, China, Quatern. Int., 218, 131-142, 2010.

Dietze, E., Hartmann, K., Diekmann, B., IJmker, J., Lehmkuhl, F., Opitz, S., Stauch, G., Wünnemann, B., and Borchers, A.: An end-member algorithm for deciphering modern detrital processes from lake sediments of Lake Donggi Cona, NE Tibetan Plateau, China, Sediment. Geol., 243-244, 169-180, 2012.

Dietze, E., Wünnemann, B., Hartmann, K., Diekmann, B., Jin, H., Stauch, G., Yang, S., and Lehmkuhl, F.: Early to mid-Holocene lake high-stand sediments at Lake Donggi Cona, northeastern Tibetan Plateau, China, Quaternary Res., 79, 325-336, 2013.
Dietze, M. and Dietze, E.: EMMAgeo: End-member modelling algorithm and supporting functions for grain-size analysis, $\mathrm{R}$ package version 0.9.0., available at: http://CRAN.R-project.org/ package=EMMAgeo (last access: 10 December 2013), 2013.

Doberschütz, S., Frenzel, P., Haberzettl, T., Kasper, T., Wang, J., Zhu, L., Daut, G., Schwalb, A., and Mäusbacher, R.: Monsoonal forcing of Holocene paleoenvironmental change on the central Tibetan Plateau inferred using a sediment record from Lake Nam Co (Xizang, China), J. Paleolimnol., 1-14, doi:10.1007/s10933013-9702-1, 2013.

Flemming, B. W.: The influence of grain-size analysis methods and sediment mixing on curve shapes and textural parameters: Implications for sediment trend analysis, Sediment. Geol., 202, 425435, 2007.

Folk, R. L. and Ward, W. C.: Brazos River bar [Texas]; a study in the significance of grain size parameters, J. Sediment. Res., 27, 3-26, 1957.

Francus, P., Bradley, R., Lewis, T., Abbott, M., Retelle, M., and Stoner, J.: Limnological and sedimentary processes at Sawtooth Lake, Canadian High Arctic, and their influence on varve formation, J. Paleolimnol., 40, 963-985, 2008.

French, H. M.: The Periglacial Environment, John Wiley \& Sons, Chichester, UK, 458 pp., 2007.

Gasse, F., Arnold, M., Fontes, J. C., Fort, M., Gibert, E., Huc, A., Bingyan, L., Yuanfang, L., Qing, L., Melieres, F., Campo, E. V., Fubao, W., and Qingsong, Z.: A 13,000-year climate record from western Tibet, Nature, 353, 742-745, 1991.

Goossens, D.: Quantification of the dry aeolian deposition of dust on horizontal surfaces: an experimental comparison of theory and measurements, Sedimentology, 52, 859-873, 2005.

Hartmann, D.: From reality to model: Operationalism and the value chain of particle-size analysis of natural sediments, Sediment. Geol., 202, 383-401, 2007.

Hesse, P. P. and McTainsh, G. H.: Last glacial maximum to early Holocene wind strength in the mid-latitudes of the Southern Hemisphere from aeolian dust in the Tasman Sea, Quaternary Res., 52, 343-349, 1999.

IJmker, J., Stauch, G., Dietze, E., Hartmann, K., Diekmann, B., Lockot, G., Opitz, S., Wünnemann, B., and Lehmkuhl, F.: Characterisation of transport processes and sedimentary deposits by statistical end-member mixing analysis of terrestrial sediments in the Donggi Cona lake catchment, NE Tibetan Plateau, Sediment. Geol., 281, 166-179, 2012.

Immerzeel, W. W., van Beek, L. P. H., and Bierkens, M. F. P.: Climate change will affect the Asian water towers, Science, 328, 1382-1385, 2010.

Kämpf, L., Brauer, A., Dulski, P., Lami, A., Marchetto, A., Gerli, S., Ambrosetti, W., and Guilizzoni, P.: Detrital layers marking flood events in recent sediments of Lago Maggiore (N. Italy) and their comparison with instrumental data, Freshwater Biol., 57, 2076-2090, 2012.

Kasper, T., Haberzettl, T., Doberschütz, S., Daut, G., Wang, J., Zhu, L., Nowaczyk, N., and Mäusbacher, R.: Indian Ocean Summer Monsoon (IOSM)-dynamics within the past $4 \mathrm{ka}$ recorded in the sediments of Lake Nam Co, central Tibetan Plateau (China), Quaternary Sci. Rev., 39, 73-85, 2012.

Kasper, T., Frenzel, P., Haberzettl, T., Schwarz, A., Daut G., Meschner S., Wang, J., Zhu, L., and Mäusbacher, R.: Interplay between redox conditions and hydrological changes in sediments 
from Lake Nam Co (Tibetan Plateau) during the past $4000 \mathrm{cal}$ BP inferred from geochemical and micropaleontological analyses, Palaeogeogr. Palaeocl., 392, 261-271, 2013.

Keil, A., Berking, J., Mügler, I., Schütt, B., Schwalb, A., and Steeb, P.: Hydrological and geomorphological basin and catchment characteristics of Lake Nam Co, South-Central Tibet, Quatern. Int., 218, 118-130, 2010.

Klovan, J. E. and Imbrie, J.: An algorithm and FORTRAN-IV program for large-scale Q-mode factor analysis and calculation of factor scores, Math. Geol., 3, 61-77, 1971.

Kropáček, J., Maussion, F., Chen, F., Hoerz, S., and Hochschild, V.: Analysis of ice phenology of lakes on the Tibetan Plateau from MODIS data, The Cryosphere, 7, 287-301, doi:10.5194/tc7-287-2013, 2013.

Kürschner, H., Herzschuh, U., and Wagner, D.: Phytosociological studies in the north-eastern Tibetan Plateau (NW China) A first contribution to the subalpine scrub and alpine meadow vegetation, Botanische Jahrbücher der Systematik, 126, 273-315, doi:10.1127/0006-8152/2005/0126-0273, 2005.

Kutzbach, J. E., Prell, W. L., and Ruddiman, W. F.: Sensitivity of Eurasian Climate to Surface Uplift of the Tibetan Plateau, J. Geol., 101, 177-190, 1993.

Liu, J., Wang, S., Yu, S., Yang, D., and Zhang, L.: Climate warming and growth of high-elevation inland lakes on the Tibetan Plateau, Global Planet. Change, 67, 209-217, 2009.

Long, H., Lai, Z., Frenzel, P., Fuchs, M., and Haberzettl, T.: Holocene moist period recorded by the chronostratigraphy of a lake sedimentary sequence from Lake Tangra Yumco on the south Tibetan Plateau, Quat. Geochronol., 10, 136-142, 2012.

Maussion, F., Scherer, D., Finkelnburg, R., Richters, J., Yang, W., and Yao, T.: WRF simulation of a precipitation event over the Tibetan Plateau, China - an assessment using remote sensing and ground observations, Hydrol. Earth Syst. Sci., 15, 1795-1817, doi:10.5194/hess-15-1795-2011, 2011.

Maussion, F., Scherer, D., Mölg, T., Collier, E., Curio, J., and Finkelnburg, R.: Precipitation seasonality and variability over the Tibetan Plateau as resolved by the High Asia Reanalysis, J. Climate, online first, doi:10.1175/JCLI-D-13-00282.1, 2013.

Miehe, S., Miehe, G., van Leeuwen, J. F. N., Wrozyna, C., van der Knaap, W. O., Duo, L., and Haberzettl, T.: Persistence of Artemisia steppe in the Tangra Yumco Basin, westcentral Tibet, China: despite or in consequence of Holocene lake-level changes?, J. Paleolimnol., J. Paleolimnol., 1-19, doi:10.1007/s10933-013-9720-z, 2013.

Miesch, A. T.: Q-mode factor analysis of compositional data, Comput. Geosci., 1, 147-159, 1976.

Mischke, S., Zhang, C., Börner, A., and Herzschuh, U.: Lateglacial and Holocene variation in aeolian sediment flux over the northeastern Tibetan Plateau recorded by laminated sediments of a saline meromictic lake, J. Quaternary Sci., 25, 162-177, 2009.

Nedell, S. S., Andersen, D. W., Squyres, S. W., and Love, F. G.: Sedimentation in ice-covered Lake Hoare, Antarctica, Sedimentology, 34, 1093-1106, 1987.

North, C. P. and Davidson, S. K.: Unconfined alluvial flow processes: Recognition and interpretation of their deposits, and the significance for palaeogeographic reconstruction, Earth-Sci. Rev., 111, 199-223, 2012.
Opitz, S., Wünnemann, B., Aichner, B., Dietze, E., Hartmann, K., Herzschuh, U., IJmker, J., Lehmkuhl, F., Li, S., Mischke, S., Plotzki, A., Stauch, G., and Diekmann, B.: Late Glacial and Holocene development of Lake Donggi Cona, north-eastern Tibetan Plateau, inferred from sedimentological analysis, Palaeogeogr. Palaeocl., 337-338, 159-176, 2012.

Pendea, I. F., Gray, J. T., Ghaleb, B., Tantau, I., Badarau, A. S., and Nicorici, C.: Episodic build-up of alluvial fan deposits during the Weichselian Pleniglacial in the western Transylvanian Basin, Romania and their paleoenvironmental significance, Quatern. Int., 198, 98-112, 2009.

Rea, D. K.: The paleoclimatic record provided by eolian deposition in the deep sea: The geologic history of wind, Rev. Geophys., 32, 159-195, 1994.

Ruth, U., Wagenbach, D., Steffensen, J. P., and Bigler, M.: Continuous record of microparticle concentration and size distribution in the central Greenland NGRIP ice core during the last glacial period, J. Geophys. Res., 108, 4098, doi:10.1029/2002JD002376, 2003.

Schieber, J., Southard, J., and Thaisen, K.: Accretion of mudstone beds from migrating floccule ripples, Science, 318, 1760-1763, 2007.

Schlütz, F. and Lehmkuhl, F.: Holocene climatic change and the nomadic Anthropocene in Eastern Tibet: palynological and geomorphological results from the Nianbaoyeze Mountains, Quaternary Sci. Rev., 28, 1449-1471, 2009.

Stauch, G. and Lehmkuhl, F.: Reconstruction of a sediment cascade on the north eastern Tibetan Plateau, EGU General Assembly, Vienna, Austria, 22-27 April 2012, EGU2012-11280, 2012.

Stauch, G., IJmker, J., Pötsch, S., Zhao, H., Hilgers, A., Diekmann, B., Dietze, E., Hartmann, K., Opitz, S., Wünnemann, B., and Lehmkuhl, F.: Aeolian sediments on the north-eastern Tibetan Plateau, Quaternary Sci. Rev., 57, 71-84, 2012.

Sturm, M. and Matter, A.: Sedimente und Sedimentationsvorgänge im Thunersee, Eclogae Geol. Helv., 65, 563-590, 1972 (in German).

Stuut, J.-B. W., Prins, M. A., Schneider, R. R., Weltje, G. J., Jansen, J. H. F., and Postma, G.: A 300-kyr record of aridity and wind strength in southwestern Africa: inferences from grain-size distributions of sediments on Walvis Ridge, SE Atlantic, Mar. Geol., 180, 221-233, 2002.

Sun, D., Bloemendal, J., Rea, D. K., Vandenberghe, J., Jiang, F., An, Z., and Su, R.: Grain-size distribution function of polymodal sediments in hydraulic and aeolian environments, and numerical partitioning of the sedimentary components, Sediment. Geol., 152, 263-277, 2002.

Sun, D., Chen, F., Bloemendal, J., and Su, R.: Seasonal variability of modern dust over the Loess Plateau of China, J. Geophys. Res., 108, 4665, doi:10.1029/2003JD003382, 2003.

Sun, D., Bloemendal, J., Rea, D. K., An, Z., Vandenberghe, J., Lu, H., Su, R., and Liu, T.: Bimodal grain-size distribution of Chinese loess, and its palaeoclimatic implications, Catena, 55, 325340, 2004.

Sun, J., Li, S.-H., Muhs, D. R., and Li, B.: Loess sedimentation in Tibet: provenance, processes, and link with Quaternary glaciations, Quaternary Sci. Rev., 26, 2265-2280, 2007. 
Torres, V., Vandenberghe, J., and Hooghiemstra, H.: An environmental reconstruction of the sediment infill of the Bogotá basin (Colombia) during the last 3 million years from abiotic and biotic proxies, Palaeogeogr. Palaeocl., 226, 127-148, 2005.

Tsoar, H. and Pye, K.: Dust transport and the question of desert loess formation, Sedimentology, 34, 139-153, 1987.

Vandenberghe, J.: Grain size of fine-grained windblown sediment: A powerful proxy for process identification, Earth-Sci. Rev., 121, 18-30, 2013.

Vandenberghe, J., Lu, H., Sun, D., van Huissteden, J., and Konert, M.: The late Miocene and Pliocene climate in East Asia as recorded by grain size and magnetic susceptibility of the Red Clay deposits (Chinese Loess Plateau), Palaeogeogr. Palaeocl., 204, 239-255, 2004.

Vriend, M. and Prins, M. A.: Calibration of modelled mixing patterns in loess grain-size distributions: an example from the northeastern margin of the Tibetan Plateau, China, Sedimentology, 52, 1361-1374, 2005.

Wang, J., Zhu, L., Daut, G., Ju, J., Lin, X., Wang, Y., Zhen, X.: Investigation of bathymetry and water quality of Lake Nam Co, the largest lake on the central Tibetan Plateau, China, Limnology, 10, 149-158, 2009.

Wang, J., Peng, P., Ma, Q., and Zhu, L.: Modern limnological features of Tangra Yumco and Zhari Namco, Tibetan Plateau, J. Lake Sci., 22, 629-632, 2010 (in Chinese).
Weltje, G.: End-member modeling of compositional data: Numerical-statistical algorithms for solving the explicit mixing problem, Math. Geol., 29, 503-549, 1997.

Weltje, G. J. and Prins, M. A.: Genetically meaningful decomposition of grain-size distributions, Sediment. Geol., 202, 409-424, 2007.

Wrozyna, C., Frenzel, P., Steeb, P., Zhu, L., van Geldern, R., Mackensen, A., and Schwalb, A.: Stable isotope and ostracode species assemblage evidence for lake level changes of Nam Co, southern Tibet, during the past 600 years, Quatern. Int., 212, 2-13, 2010.

Wu, G., Yao, T., Xu, B., Tian, L., Zhang, C., and Zhang, X.: Dust concentration and flux in ice cores from the Tibetan Plateau over the past few decades, Tellus B, 62, 197-206, 2010.

Xu, H., Hou, Z. H., Ai, L., and Tan, L. C.: Precipitation at Lake Qinghai, NE Qinghai-Tibet Plateau, and its relation to Asian summer monsoons on decadal/interdecadal scales during the past 500 years, Palaeogeogr. Palaeocl., 254, 541-549, 2007.

Zhang, X. Y., Arimoto, R., Cao, J. J., An, Z. S., and Wang, D.: Atmospheric dust aerosol over the Tibetan Plateau, J. Geophys. Res., 106, 18471-18476, 2001. 